\title{
Pharmacological Profiles of Aspergillomarasmines as Endothelin Converting Enzyme Inhibitors
}

\author{
Akihiro Matsuura, Hiroshi Okumura, Rieko Asakura, Naoki Ashizawa, Mayumi Takahashi, \\ Fujio Kobayashi, Nami Ashikawa and Koshi Arai \\ Pharmaceutical Research Laboratories, Sapporo Breweries, Ltd., 10 Okatohme, Yaizu, Shizuoka 425, Japan
}

Received April 22, $1993 \quad$ Accepted July 7, 1993

\begin{abstract}
Aspergillomarasmine-A and -B (AM-A and -B), which were isolated from the cultured broth of an unidentified fungus N877, showed apparent inhibition against endothelin-converting enzyme (ECE) from bovine endothelial cells as measured by the formation of endothelin-1 (ET-1) converted from big endothelin-1 (bET-1), with IC $_{50}$ values of 3.4 and $2.5 \mu \mathrm{M}$ for AM-A and -B, respectively. EDTA also inhibited ECE $\left(\mathrm{IC}_{50}=1.1 \mu \mathrm{M}\right)$, but the inhibitions by AM-A, AM-B and EDTA were each abolished by the addition of $10 \mu \mathrm{M} \mathrm{Zn}{ }^{2+}$ to the reaction mixture. In mice, AM-A and -B dose-dependently $(10-50 \mathrm{mg} / \mathrm{kg}$, i.v.) caused significant prolongation of the latency to sudden death induced by i.v. bET-1 $(25 \mathrm{nmol} / \mathrm{kg})$, but not that by ET-1 $(5 \mathrm{nmol} / \mathrm{kg})$, accompanied by a decrease in plasma immunoreactive ET-1 formation, while EDTA $\left(24 \mathrm{mg} / \mathrm{kg}\right.$ ) failed to do so. In mice, the $\mathrm{LD}_{50}$ value of AM-A was calculated to be $159.8 \mathrm{mg} / \mathrm{kg}$, i.v., which was much larger than that of EDTA $(28.5 \mathrm{mg} / \mathrm{kg}$, i.v.), indicating the low toxicity of AM-A. AM-A (30 $\mathrm{mg} / \mathrm{kg}$, i.v.) also suppressed bET-1-induced hemoconcentration and hypertension in mice and rats, respectively. These findings suggest that although ECE inhibition by AM-A was mainly attributable to its chelating activity, it showed apparent in vivo activities due to ECE inhibition with low toxicity.
\end{abstract}

Keywords: Aspergillomarasmine, Endothelin-1, Big endothelin-1, Endothelin converting enzyme, EDTA

Endothelin-1 (ET-1) is biosynthesized through the conversion of its precursor big endothelin-1 (bET-1) by a specific endothelin-converting enzyme (ECE) (1). ECE has been proposed to be a phosphoramidon-inhibitable metalloprotease, which has been detected in endothelial cells (ECs) $(2,3)$ and vascular smooth muscle cells $(4)$. Phosphoramidon (PA), a metalloprotease inhibitor, was reported to suppress bET-1-induced responses in vivo such as sudden death $(5)$, hypertension $(6,7)$, hemoconcentration (8) and enhancement of vascular permeability (9) as well as found to inhibit ECE in vitro $(10,11)$.

Although several inhibitors besides phosphoramidon were claimed to inhibit ECE, most of them did not inhibit ECE specifically and intensely. ECE was also inhibited by metal chelating agents; therefore, $5 \mathrm{mM}$ EDTA inhibited ECE when the conversion occurred at $\mathrm{pH} 7.0$ (12). Aspergillomarasmine-A and -B (AM-A and -B), phytotoxins produced by several phytopathogeneous fungi (13), are known to cause a disturbance of the water balance and wilting effects in plant leaves by their $\mathbf{F e}^{3+}$-chelating activity (14). AM-A and -B also have abilities to inhibit angiotensin-converting enzyme (ACE) (15). Recently, we have found that AM-A and $-\mathrm{B}$, which were isolated from the cultured broth of an unidentified fungus N877, have an intense inhibitory activity against ECE from bovine endothelial cells. In the present study, we have further evaluated the pharmacological profiles of AM-A and -B in both in vitro and in vivo experiments, in contrast to the profiles of EDTA and PA.

\section{MATERIALS AND METHODS}

\section{Animals and drugs}

Male ICR mice (6- to 7-week-old; Charles River Japan, Inc., Atsugi) and male Sprague-Dawley rats $(250-350 \mathrm{~g}$, Charles River Japan, Inc.) were used.

Human ET-1, human bET-1, PA, E-64 and pepstatin A were purchased from the Peptide Institute, Inc. (Osaka). Rabbit IgG anti ET(15-21) and rabbit IgG F(ab')2HRP were obtained from International Reagents Corp. (Kobe). Diisopropyl fluorophosphate (DFP) and Triton X100 were obtained from Wako Pure Chemical Industries (Osaka). Actinonin, aprotinin and EDTA were purchased from Sigma (St. Louis, MO, USA), Seikagaku 
Corp. (Tokyo) and Dojindo Labs. (Kumamoto), respectively.

\section{Preparation of membrane ECE}

ECs of a bovine aorta grown to a confluent monolayer were rinsed with phosphate-buffered saline (PBS, $\mathrm{pH}$ 7.4) and detached from the culture flasks by using $0.2 \%$ trypsin. ECs were homogenized in ice-cold Buffer A, $50 \mathrm{mM}$ sodium phosphate buffer ( $\mathrm{pH} 7.0$ ) containing $0.1 \mathrm{mM}$ E$64,1 \mathrm{mM}$ DFP and $10 \mu \mathrm{M}$ pepstatin A, with a glass homogenizer; and then the homogenate was centrifuged at $10,000 \times \mathrm{g}$ for $20 \mathrm{~min}$ at $4^{\circ} \mathrm{C}$. The precipitate was then sonicated for $3 \mathrm{~min}$ at $0^{\circ} \mathrm{C}$, centrifuged at $100,000 \times g$ for $60 \mathrm{~min}$, resuspended in Buffer A by a sonicator and stored at $-80^{\circ} \mathrm{C}$.

\section{ECE inhibition in vitro}

After preincubation of the inhibitor with crude ECE (5 $\mu \mathrm{g}$ protein) in $124 \mu \mathrm{l}$ of $200 \mathrm{mM}$ Tris- $\mathrm{HCl}$ buffer ( $\mathrm{pH} 7.0)$ containing $10 \mu \mathrm{M}$ actinonin for $10 \mathrm{~min}, 100 \mathrm{nM}$ bET-1 as a substrate was added to the reaction mixture. In some experiments, $10 \mu \mathrm{M} \mathrm{ZnCl}$ or $\left[1.8 \mathrm{mM} \mathrm{CaCl}_{2}\right.$ and $0.5 \mathrm{mM}$ $\mathrm{MgCl}_{2}$ ] were added to the reaction mixture to examine the effect of $\mathrm{Zn}^{2+}$ or $\left[\mathrm{Ca}^{2+}\right.$ and $\left.\mathrm{Mg}^{2+}\right]$. Then the mixture was incubated at $37^{\circ} \mathrm{C}$ for $4 \mathrm{hr}$. The reaction was stopped by heating at $100^{\circ} \mathrm{C}$ for $5 \mathrm{~min}$. After cooling with ice, the amount of immunoreactive ET-1 (IR-ET-1) in the reaction mixture was measured by EIA. Sandwich-EIA was employed using a rabbit IgG anti ET(15-21)-coated microtest plate. After blocking with $1 \%$ BSA, the plate was reacted with standard ET-1 or the reaction mixture, followed by a reaction with rabbit IgG F(ab')2-HRP anti ET -1 . The plate was washed with the buffer $(0.1 \%$ Triton $\mathrm{X} 100$ in PBS), and then the bound enzyme activity was measured with $o$-phenylenediamine as a chromogen. The assay showed no cross-reactivity with $\mathrm{bET}-1$ at the concentration of $100 \mathrm{nM}$.

\section{Effects on sudden death induced by bET-1 and ET-1 in mice}

Both AM-A and -B (Fig. 1) were suspended in saline containing $0.5 \%$ carboxymethylcellulose (CMC-saline). $\mathrm{AM}-\mathrm{A}$ or $-\mathrm{B}$ at a dose of 10 or $50 \mathrm{mg} / \mathrm{kg}$ was intravenously administered to mice $10 \mathrm{~min}$ before the injection of bET-1 $(25 \mathrm{nmol} / \mathrm{kg}$, i.v.) dissolved in saline. This dose of bET-1 was reported to have an almost complete lethality in mice (5). In control animals, CMC-saline was given as a vehicle. Mortality $(\%)$ and latency $(\mathrm{sec})$ to death, as judged by the cessation of respiration, were measured up to $60 \mathrm{~min}$ after bET-1 injection. PA ( $2 \mathrm{mg} / \mathrm{kg}$, i.v.), dissolved in CMC-saline, was employed as a positive reference compound.

To acertain the specificity for ECE, the effects on ET-1-<smiles>NC(CNC(CNC(CC(=O)O)C(=O)O)C(=O)O)C(=O)O</smiles>

Aspergillomarasmine $\mathrm{A}$ (AM-A)

$$
\mathrm{C}_{10} \mathrm{H}_{17} \mathrm{~N}_{3} \mathrm{O}_{8}
$$<smiles>O=C(O)CNC(CNC(CC(=O)O)C(=O)O)C(=O)O</smiles>

Aspergillomarasmine $\mathrm{B}$ ( $\mathrm{AM}-\mathrm{B}$ )

$$
\mathrm{C}_{9} \mathrm{H}_{14} \mathrm{~N}_{2} \mathrm{O}_{8}
$$

Fig. 1. Chemical structures of aspergillomarasmine-A and -B.

induced lethality were also examined in mice according to the previously described method (5). AM-A $(50 \mathrm{mg} / \mathrm{kg}$ ), AM-B (50 mg $/ \mathrm{kg})$, EDTA (24 mg/kg), PA ( $2 \mathrm{mg} / \mathrm{kg})$, or $\mathrm{CMC}$-saline was intravenously injected; and $10 \mathrm{~min}$ later, ET-1 dissolved in saline was administered at the dose of 5 $\mathrm{nmol} / \mathrm{kg}$, i.v. Mortality and latency to death were then measured as described above.

\section{Measurement of plasma IR-ET-I in mice}

CMC-saline, AM-A ( $50 \mathrm{mg} / \mathrm{kg})$, EDTA $(24 \mathrm{mg} / \mathrm{kg}$ ) or PA $(2 \mathrm{mg} / \mathrm{kg})$ was intravenously given to mice $10 \mathrm{~min}$ prior to bET-1 injection ( $25 \mathrm{nmol} / \mathrm{kg}, \mathrm{i} . \mathrm{v}$.$) ; and there-$ after, blood samples were collected by cardiac puncture at 5 min after bET-1 injection. The blood samples were placed in chilled tubes containing aprotinin $(300 \mathrm{KIU} / \mathrm{ml})$ and EDTA $(2 \mathrm{mg} / \mathrm{ml})$ and centrifuged at $2000 \times \mathrm{g}$ for 15 min at $4^{\circ} \mathrm{C}$. A plasma sample diluted ten times with PBS was added to the microtest plate. Plasma IR-ET-1 was measured by sandwich-EIA as described above.

\section{Acute toxicity in male ICR mice}

Acute toxicities of AM-A and EDTA were evaluated in mice. AM-A and EDTA were intravenously given at doses of $125,140,165,200$ and $250 \mathrm{mg} / \mathrm{kg}$ for AM-A and at doses of $26,28,30$ and $35 \mathrm{mg} / \mathrm{kg}$ for EDTA. The $\mathrm{LD}_{50}$ values based on 24-hr mortality were statistically analyzed by the Probit method. Six to eight mice were used for each dose of the compounds.

Effects on hemoconcentration induced by bET-I in mice CMC-saline, AM-A $(30 \mathrm{mg} / \mathrm{kg})$ or PA $(10 \mathrm{mg} / \mathrm{kg})$ was intravenously given to mice $10 \mathrm{~min}$ prior to $\mathrm{bET}-1$ injection $(10 \mathrm{nmol} / \mathrm{kg}, \mathrm{i} . v$.$) as previously reported by$ 
Okumura et al. (8). Blood samples were collected from the orbital sinus using glass capillaries precoated with heparin at $10 \mathrm{~min}$ after bET-1 injection. The hematocrit $(\mathrm{Ht})$ was measured by centrifuging the blood at 12,000 rpm for $5 \mathrm{~min}$.

The effects of AM-A and PA on ET-1-induced hemoconcentration were also examined in mice as previously described (8). Ten minutes after the administration of i.v. saline, AM-A $(30 \mathrm{mg} / \mathrm{kg})$ or PA $(10 \mathrm{mg} / \mathrm{kg}), \mathrm{ET}-1$ at a dose of $2.5 \mathrm{nmol} / \mathrm{kg}$, i.v. was injected. Blood samples were collected to measure the hematocrit, as described above, $10 \mathrm{~min}$ after the ET-1 injection.

\section{Effects on hypertension induced by bET-I in anesthetized rats}

Rats were anesthetized with sodium pentobarbital $(60 \mathrm{mg} / \mathrm{kg}$, i.p.). After tracheal intubation, polyethylene catheters were inserted into the left carotid artery and the left femoral vein for the continuous measurement of blood pressure and for drug administration, respectively. Ten minutes after the intravenous adminstration of CMC-saline, AM-A (30 mg $/ \mathrm{kg})$ or PA $(10 \mathrm{mg} / \mathrm{kg})$, bET-1 $(1 \mathrm{nmol} / \mathrm{kg}$ ) was injected to cause hypertension. Mean arterial blood pressure (MBP) was recorded on a polygraph (RM-6000; Nihon Kohden, Tokyo) via a pressure transducer (TP-300T, Nihon Kohden) attached to the end of the catheter for $120 \mathrm{~min}$ after bET-1 injection. In some rats treated with $\mathrm{AM}-\mathrm{A}, \mathrm{CMC}$-saline was injected instead of bET-1 for the assessment of the effect of AM-A alone on MBP.

\section{Statistical analyses}

Data are expressed as means \pm S.E. of observations. Mortality at $60 \mathrm{~min}$ after ET-1 or bET-1 injection was evaluated by the Fisher exact probability test. If an animal survived over $60 \mathrm{~min}$, its latency was regarded as $3600 \mathrm{sec}$. Differences in latency, the Ht, plasma IR-ET-1 and MBP among the groups were determined by an unpaired Student's $t$-test or a one-way analysis of variance with the Bonferroni modification. $P$ values less than 0.05 were regarded as statistically significant.

\section{RESULTS}

\section{Inhibition of ECE}

In the absence of $\mathrm{Zn}^{2+}, \mathrm{AM}-\mathrm{A}, \mathrm{AM}-\mathrm{B}, \mathrm{PA}$ and EDTA effectively inhibited $\mathrm{ECE}$ with $\mathrm{IC}_{50}$ values of $3.4,2.5,0.8$ and $1.1 \mu \mathrm{M}$, respectively. When $\mathrm{Zn}^{2+}(10 \mu \mathrm{M})$ was added to the reaction mixture, AM-A, AM-B and EDTA lost their ECE inhibitory activities, but PA sustained its activity (Table 1). Addition of $\mathrm{Mg}^{2+}$ and $\mathrm{Ca}^{2+}$ at the same concentration of those in Tyrode solution to the reaction mixture did not affect the inhibitory activity of AM-A against
Table 1. Inhibition of membrane ECE by aspergillomarasmine-A (AM-A) and -B (AM-B), phosphoramidon (PA) and EDTA with or without metal ions

\begin{tabular}{|c|c|c|c|c|}
\hline & \multicolumn{4}{|c|}{$\mathrm{IC}_{50}(\mu \mathrm{M})$} \\
\hline & $\mathrm{Zn}^{2+}$ & -. & + & - \\
\hline & $\mathrm{Ca}^{2-}, \mathrm{Mg}^{2+}$ & - & - & + \\
\hline AM-A & & 3.4 & $>30$ & 2.7 \\
\hline AM-B & & 2.5 & $>30$ & N.T \\
\hline $\mathrm{PA}$ & & 0.4 & 0.4 & N.T \\
\hline EDTA & & 1.1 & $>100$ & 27 \\
\hline
\end{tabular}

Membrane ECE was prepared from the bovine aorta by the procedure described in Materials and Methods. $\mathrm{ZnCl}_{2}(10 \mu \mathrm{M})$ or $\mathrm{CaCl}_{2}$ $(1.8 \mathrm{mM})$ and $\mathrm{MgCl}_{2}(0.5 \mathrm{mM})$ were added to the reaction mixture when the effects of metal ions were examined. $\mathrm{IC}_{50}$ data were determined in an EIA assay using bET-1 as substrate. N.T.: not tested.

ECE but attenuated that of EDTA (Table 1).

\section{Effects on sudden death induced by bET-1 and ET-1 in mice}

Intravenous administration of bET-1 $(25 \mathrm{nmol} / \mathrm{kg})$ to mice caused a slower onset of sudden death with a mean latency to death of $663.6-932.3 \mathrm{sec}$ ( 5 experiments) compared to that caused by ET-1 $(5 \mathrm{nmol} / \mathrm{kg}$, mean latency $=260.9 \mathrm{sec}$ ) as observed in our previous report (5). In bET-1-induced sudden death, although AM-A and -B failed to alleviate mortality, the two compounds signifi-

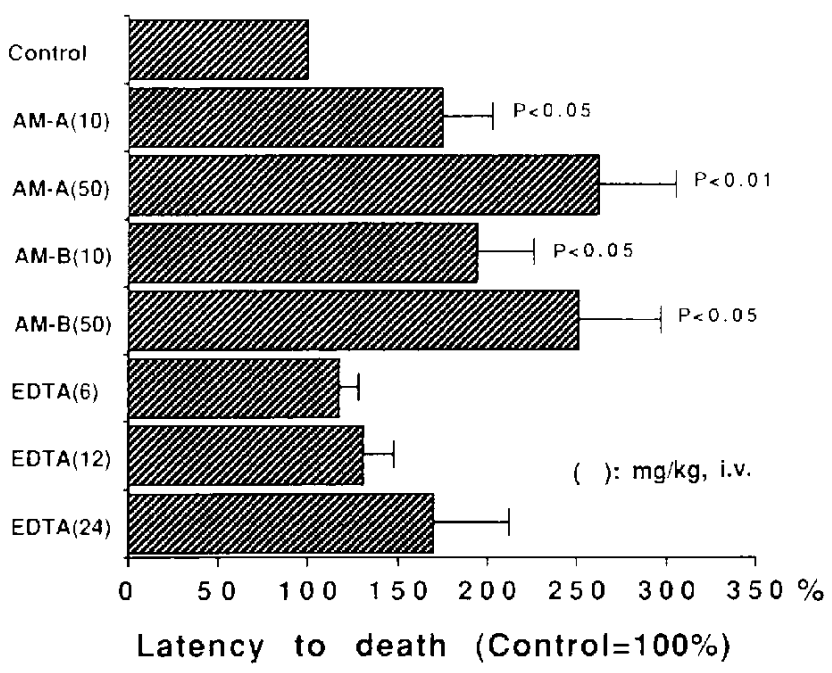

Fig. 2. Effects of pretreatment with aspergillomarasmine-A (AMA), -B (AM-B) and EDTA on big endothelin-1 (bET-1)-induced sudden death in mice $(n=6-9)$. AM-A, AM-B or EDTA was i.v. administered at the dose shown in parentheses in Figure 10 min prior to bET-1 (25 nmol $/ \mathrm{kg}$, i.v.) injection. Latency to death was expressed as a percentage of the control (control $=100 \%$ ). Data are means \pm S.E. of observations. 
Table 2. Effects of aspergillomarasmine-A (AM-A), -B (AM-B), phosphoramidon (PA) and EDTA on big endothelin-1 (bET-1)- and ET-1-induced sudden death

\begin{tabular}{|c|c|c|c|c|c|}
\hline & \multirow{2}{*}{$\begin{array}{c}\text { Dose } \\
\text { (mg/kg, i.v.) }\end{array}$} & \multicolumn{2}{|c|}{ bET-1-induced sudden death } & \multicolumn{2}{|c|}{ ET-1-induced sudden death } \\
\hline - & & $\begin{array}{c}\text { mortality } \\
(\% 0)\end{array}$ & $\begin{array}{c}\text { latency } \\
(\%)\end{array}$ & $\begin{array}{c}\text { mortality } \\
(\%)\end{array}$ & $\begin{array}{c}\text { latency } \\
(\%)\end{array}$ \\
\hline Control & - & 100 & 100 & 100 & 100 \\
\hline AM-A & 50 & 85.7 & $262.1 \pm 42.6^{* *}$ & 100 & $131.4 \pm 33.3$ \\
\hline AM-B & 50 & 85.7 & $250.9 \pm 46.0^{*}$ & 100 & $120.3 \pm 70.4$ \\
\hline PA & 2 & $0^{* *}$ & $393.5 \pm 0^{1) * *}$ & 100 & $81.7 \pm 10.0$ \\
\hline EDTA & 24 & 85.7 & $169.0 \pm 43.4$ & 100 & $72.8 \pm 15.4$ \\
\hline
\end{tabular}

bET-1 (25 nmol $/ \mathrm{kg}$, i.v.) or ET-1 ( $5 \mathrm{nmol} / \mathrm{kg}$, i.v.) was used to induce sudden death in male ICR mice $(n=6-9)$. Sudden death was judged by the cessation of respiration. Mortality was assessed at $60 \mathrm{~min}$ after bET-1 injection. Latency to death was expressed as a percentage of the control (control $=100 \%$ ). "Since no mice died for $60 \mathrm{~min}$ after bET-1 injection, the latency was regarded as $3600 \mathrm{sec}$ and calculated as a percentage of the control. ${ }^{*} \mathrm{P}<0.05,{ }^{* *} \mathrm{P}<0.01$ : Significantly different from the control.

cantly prolonged the latency to death in a dose-dependent manner at doses of 10 and $50 \mathrm{mg} / \mathrm{kg}$, i.v. (Fig. 2 and Table 2). EDTA did not improve any parameters even at a dose of $24 \mathrm{mg} / \mathrm{kg}$, i.v., while PA ( $2 \mathrm{mg} / \mathrm{kg}$, i.v.) completely suppressed mortality $(\mathrm{P}<0.01)$. These compounds, however, did not provoke any mitigation in ET-1 ( $5 \mathrm{nmol} / \mathrm{kg}$, i.v.)-induced sudden death (Table 2 ).

\section{Effects on bET-1-induced elevation of plasma IR-ET-1 in mice}

Elevation of plasma IR-ET-1 induced by bET-1 (25 $\mathrm{nmol} / \mathrm{kg}$, i.v.) and the effects of AM-A, EDTA and PA were examined 5 min after bET-1 injection in mice. As shown in Table 3, the concentration of plasma IR-ET-1 reached $67.8 \mathrm{pg} / \mathrm{ml}$ at $5 \mathrm{~min}$, which was not considered to be the maximum response, as observed in our previous report (5). Pretreatment with AM-A (50 mg/ $\mathbf{k g}$, i.v.) or PA ( $2 \mathrm{mg} / \mathrm{kg}$, i.v.) definitely lowered plasma IR-ET-1 by $76.0 \%$ and $43.1 \%$, respectively, at 5 min after bET- 1 injection, while EDTA $(24 \mathrm{mg} / \mathrm{kg}$, i.v.), in spite of showing

Table 3. Effects of Aspergillomarasmine-A (AM-A), EDTA and phosphoramidon (PA) on big endothelin-1 (bET-1)-induced elevation of plasma immunoreactive ET-1 (IR-ET-1) in mice

\begin{tabular}{lccc}
\hline & $\begin{array}{c}\text { Dose } \\
(\mathrm{mg} / \mathrm{kg}, \mathrm{i} . \mathrm{v})\end{array}$ & $\begin{array}{c}\text { Plasma IR-ET-1 } \\
(\mathrm{pg} / \mathrm{ml})\end{array}$ & $\begin{array}{c}\%_{0} \text { Decrease } \\
\text { from control }\end{array}$ \\
\cline { 3 - 4 } Control & - & $67.8 \pm 7.0$ & 0 \\
AM-A & 50 & $16.3 \pm 1.4^{* *}$ & 76.0 \\
EDTA & 24 & $60.9 \pm 4.1$ & 10.2 \\
PA & 2 & $38.6 \pm 2.9^{*}$ & 43.1 \\
\hline
\end{tabular}

Seven male ICR mice were used in each experiment. Plasma samples for the measurement of IR-ET-1 were collected by cardiac puncture at $5 \mathrm{~min}$ after bET-1 $(25 \mathrm{nmol} / \mathrm{kg}$, i.v. $)$ injection. ${ }^{*} \mathbf{P}<0.05$, ${ }^{* *} \mathrm{P}<0.01$ : Significantly different from the control.
ECE inhibition in vitro, did not. AM-A and PA at the same doses also suppressed the elevation of plasma IRET-1 even at $15 \mathrm{~min}$ after the injection of bET-1 (data not shown).

\section{Acute toxicity in male ICR mice}

Mortality was measured at the dose range of $125-250$ $\mathrm{mg} / \mathrm{kg}$, i.v. for AM-A and $26-35 \mathrm{mg} / \mathrm{kg}$, i.v. for EDTA. The $\mathrm{LD}_{50}$ value of $\mathrm{AM}-\mathrm{A}$ was calculated to be 159.8 $\mathrm{mg} / \mathrm{kg}$, i.v., which was much larger than that of EDTA ( $28.5 \mathrm{mg} / \mathrm{kg}$, i.v.). This indicates the lower toxicity of AM-A as compared to EDTA.

Effects on hemoconcentration induced by bET-1 in mice

The injection of bET-1 (10 nmol/ $\mathrm{kg}$, i.v.) induced a significant increase in $\mathrm{Ht}$, namely hemoconcentration, by $12.4 \%$ (Fig. 3, from $46.50 \pm 0.43$ to $52.25 \pm 0.89$, $\mathrm{P}<0.01)$. The increase in $\mathrm{Ht}$ by bET-1 continued at least 120 min after the injection (8). Pretreatment with AM-A $(30 \mathrm{mg} / \mathrm{kg}$, i.v.) or PA $(10 \mathrm{mg} / \mathrm{kg}$, i.v.) significantly inhibited bET-1-induced hemoconcentration by $66.6 \%$ for AM-A $(\mathrm{P}<0.01)$ and $39.1 \%$ for PA $(\mathrm{P}<0.05)$ (Fig. 3). Neither AM-A nor PA alone affected the basal $\mathrm{Ht}$ (data not shown).

The effects of AM-A and PA on ET-1-induced hemoconcentration in mice were also examined to clarify the influence of these inhibitors on ET-1 degradation. ET-1 $(2.5 \mathrm{nmol} / \mathrm{kg}$, i.v.) caused a significant increase in hematocrit (from 48.3 to $52.9 \%, \mathrm{P}<0.01$ ). Pretreatment with AM-A $(30 \mathrm{mg} / \mathrm{kg}$, i.v.) or PA $(10 \mathrm{mg} / \mathrm{kg}$, i.v.) failed to inhibit ET-1-induced hemoconcentration $(52.7 \%$ for AM-A and $54.1 \%$ for PA). 


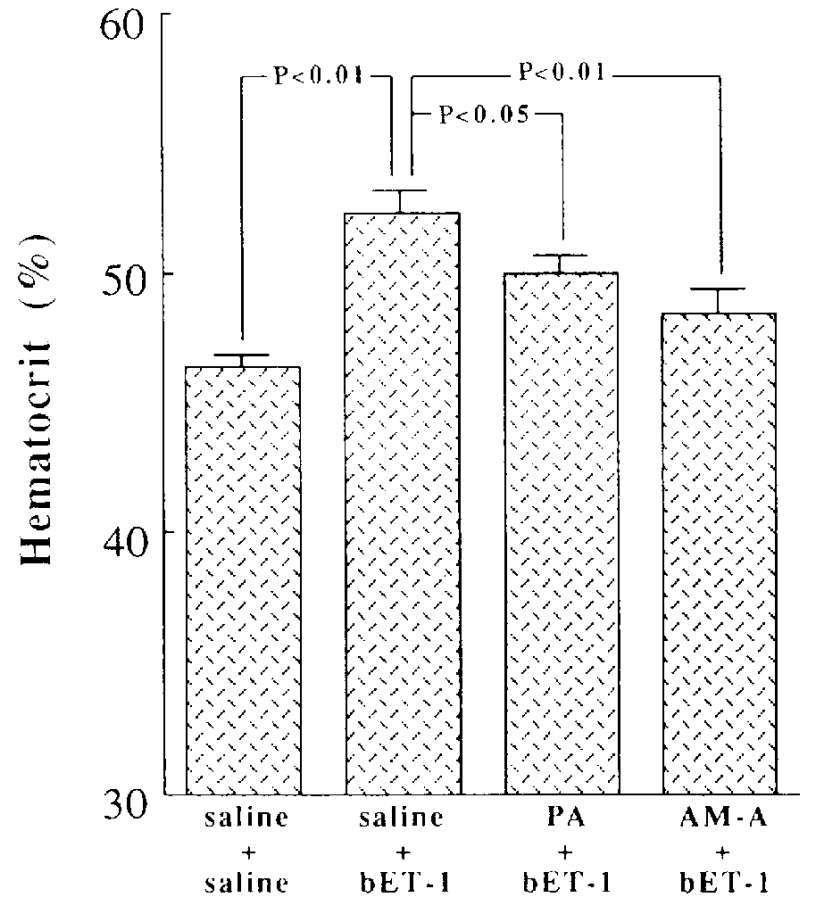

Fig. 3. Effects of pretreatment with phosphoramidon (PA, 10 $\mathrm{mg} / \mathrm{kg}, \mathrm{i} . v$.) and aspergillomarasmine-A (AM-A; $30 \mathrm{mg} / \mathrm{kg}$, i.v.) on big endothelin-1 (bET-1)-induced increase in hematocrit (hemoconcentration) in mice $(\mathrm{n}=6-8)$. PA or AM-A was i.v. administered $10 \mathrm{~min}$ prior to $\mathrm{bET}-1(10 \mathrm{nmol} / \mathrm{kg})$ injection. Blood samples were collected from the orbital sinus $10 \mathrm{~min}$ after bET-1 injection. The hematocrit was measured by centrifuging the blood at $12,000 \mathrm{rpm}$ for $5 \mathrm{~min}$ and is expressed in \%. Data are means \pm S.E. of observations.
Effects on hypertension induced by bET-1 in anesthetized rats

As shown in Fig. 4, the injection of bET-1 $(1 \mathrm{nmol} / \mathrm{kg}$, i.v.) caused a progressive increase in MBP. Pretreatment with AM-A ( $30 \mathrm{mg} / \mathrm{kg}$, i.v.) remarkably inhibited bET-1induced hypertension; and in a later phase $(60 \mathrm{~min}$ after bET-1 injection), it induced hypotension in spite of bET1 treatment. AM-A alone, however, did not exert any significant effects on basal MBP. PA at a dose of $10 \mathrm{mg} / \mathrm{kg}$, i.v., which was higher than that required to inhibit bET1 -induced lethality, also attenuated the increase in MBP induced by bET-1 (Fig. 4).

\section{DISCUSSION}

ECE has been claimed to be a metalloprotease because ECE activities in vitro and in vivo are effectively blocked by a metalloprotease inhibitor, phosphoramidon. EDTA and EGTA, metal chelators, concentration-dependently inhibited EC activities in the homogenate of cultured bovine aortic endothelial cells (2). Several metal ions, such as $\mathrm{Zn}^{2+}, \mathrm{Mn}^{2+}, \mathrm{Fe}^{2+}$ and $\mathrm{Co}^{2-}$, reactivated ECE once inactivated by EDTA (10). In the present study, addition of $\mathrm{Zn}^{2+}$ to the reaction mixture resulted in attenuation of ECE inhibition by AM-A, AM-B and EDTA (Table 1). These chelators also inhibited ACE, which could be reversed by the addition of stoichiometric $\mathrm{Zn}^{2+}$ to the reaction mixture $(15,16)$. These observations imply that

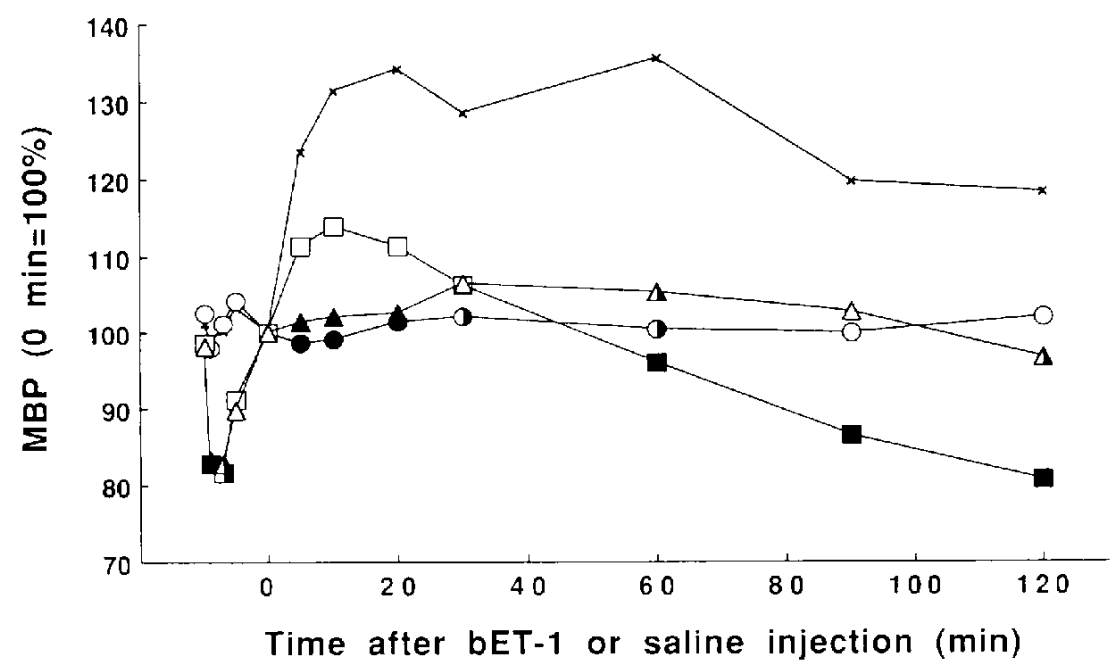

Fig. 4. Effects of aspergillomarasmine-A (AM-A) and phosphoramidon (PA) on big endothelin-1 (bET-1)-induced changes of mean arterial blood pressure (MBP) in anesthetized rats. Four male Sprague-Dawley rats per group were used. Saline (1 ml $/ \mathrm{kg})$, AM-A $(30 \mathrm{mg} / \mathrm{kg})$ or PA $(10 \mathrm{mg} / \mathrm{kg})$ was i.v. administered $10 \mathrm{~min}$ prior to $\mathrm{bET}-1(1 \mathrm{nmol} / \mathrm{kg})$ injection. One group pretreated with AM-A was given saline instead of bET-1 for the assessment of the effect of AM-A alone. Changes in MBP are expressed as percentages of MBP 0 min after the bET- 1 or saline injection $(0 \mathrm{~min}=100 \%)$. Data are means of observations. $\times:$ Saline + bET1 control, $\bigcirc:$ PA+bET-1; significantly different from saline+bET-1 control at $\mathrm{P}<0.05$ (O) or $\mathrm{P}<0.01$ (O). $\triangle:$ AM-

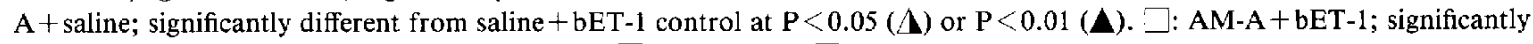

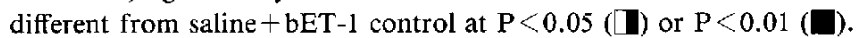


the ECE inhibitory activities of AM-A, AM-B and EDTA are mainly consequences of their metal chelating activities.

Inhibition of ECE in vivo, however, differed among the metal chelators. As shown in Tables 2 and 3, AM-A and -B significantly suppressed sudden death and elevation of plasma IR-ET-1 provoked by bET-1 in mice (AM-B was not tested in the study for IR-ET-1 measurement), but EDTA failed to inhibit these responses even at a dose of $24 \mathrm{mg} / \mathrm{kg}$, i.v., which was the highest possible dose considering its marked toxicity $\left(\mathrm{LD}_{50}=28.5 \mathrm{mg} / \mathrm{kg}\right.$, i.v.). Our present study also clearly demonstrates that EDTA lost its inhibitory activity against ECE in vitro in the presence of $\mathrm{Ca}^{2+}$ and $\mathrm{Mg}^{2+}$ at concentrations almost equivalent to those in plasma, while AM-A sustained its activity (Table 1). This indicates that EDTA would lose its ability to inhibit ECE as soon as it appeared in the blood, where $\mathrm{Ca}$ and several metal ions were abundant. Thus the intense metal chelating activity of EDTA would result not only in striking inhibition of ECE in vitro but also result in nonselective and rapid chelation of metal ions existing in the blood when intravenously administered to mice, leading to insufficient inhibition of ECE and to high toxicity in vivo. On the other hand, the chelating activity of AM-A with $\mathrm{Ca}^{2+}$ and $\mathrm{Mg}^{2+}$ was so weak that it could preserve the ability of the ECE inhibition in vivo with low toxicity.

In this connection, our previous study also demonstrated that inhibition of bET-1-induced lethality by PA was closely relevant to the decrement in plasma IR-ET-1 formation (5). In the present study, a causal relationship between the plasma IR-ET-1 level and the mitigation of bET-1-induced lethality was observed between AM-A and EDTA and between PA and EDTA. The relationship between AM-A and PA, however, was reversed: At $5 \mathrm{~min}$ after bET-1 injection, PA lowered plasma IR-ET-1 less effectively than did AM-A, whereas PA completely abolished sudden death, but AM-A did so incompletely. At $15 \mathrm{~min}$ after bET-1 injection, both compounds surely suppressed the elevation of plasma IR-ET-1 by the same degree (data not shown). These data indicate that plasma IR-ET-1 would not be a crucial factor in bET-1-induced sudden death; instead, tissue IR-ET-1 in the lung, vasculature and so on would also be important for bET-1-induced sudden death.

In the experiments of bET-1-induced hemoconcentration (Fig. 3) and hypertension (Fig. 4), the doses of bET-1 employed were 10 and $1 \mathrm{nmol} / \mathrm{kg}$, i.v., respectively, which were much lower than that employed in the bET-1induced sudden death experiment $(25 \mathrm{nmol} / \mathrm{kg})$. In those cases, AM-A at a dose equal to that for the sudden death displayed sufficient inhibition of ECE followed by significant attenuation of bET-1-induced hemoconcentra- tion and hypertension. This suggests that AM-A would be able to suppress ECE almost completely followed by the attenuation of bET-1-induced phenomena when bET-1 as a substrate for ECE is very low in concentration. On the contrary, a higher dose of PA $(10 \mathrm{mg} / \mathrm{kg}$, i.v. $)$ was required to obtain significant inhibition against these bET1 -induced reactions compared to that against the sudden death $(2 \mathrm{mg} / \mathrm{kg})$. Matsumura et al. (6) reported that they used $0.25 \mathrm{mg} / \mathrm{kg} / \mathrm{min}$ of PA at least $30 \mathrm{~min}$ prior to bET1 injection and thereafter over a 40 -min experiment period, estimating that at least $10-20 \mathrm{mg} / \mathrm{kg}$ of PA is required for suppression of the pressor response. Since hemoconcentration (8) and hypertension (1) were reported to be easily induced by a small amount of ET-1, these two responses would also be induced by a small amount of bET-1, as a precursor of ET-1. Accordingly, a small quantity of ET-1, which was converted from bET-1 despite ECE inhibition by PA at the lower dose of 2 $\mathrm{mg} / \mathrm{kg}$, i.v., was able to induce hemoconcentration and hypertension. In other words, complete inhibition of ET1 production leads to prevention of the two reactions induced by bET-1. As for bET-1-induced sudden death, a high dose of bET-1 ( $25 \mathrm{nmol} / \mathrm{kg}$, i.v. $)$ is necessary to achieve complete lethality (5). The $\mathrm{LD}_{50}$ value of bET-1 was estimated to be $21.0 \mathrm{nmol} / \mathrm{kg}$, i.v., and the sudden death completely disappeared when the dose of bET-1 was decreased to $15 \mathrm{nmol} / \mathrm{kg}$. These results indicate that bET-1-induced sudden death is vulnerable to changes in the amount of exogeneously given bET-1, i.e., that of ET-1 converted by ECE or that of ET-1 formation inhibited by PA.

In the present study, AM-A caused hypotension in a later phase after bET-1 injection, while AM-A alone did not. It has been reported that ET simulates atrial natriuretric peptide (ANP) (17), which successively caused hemoconcentration (8). ANP is also known as a hypotensive factor and is degraded by neutral endopeptidases (NEP). Since AM-A would inhibit NEP by its chelating activity, it would inhibit the degradation of ANP, which would lead to hypotension. In mice, however, AM-A failed to increase the plasma ANP level at 60 or $120 \mathrm{~min}$ after bET-1 injection (data not shown). This indicates that the hypotension caused by AM-A in a later phase after bET-1 injection was not due to ANP and that other unknown factor(s) would be involved in the phenomenon.

Taking into consideration our findings showing that AM-A has a lower toxicity than EDTA, AM-A, as well as AM-B, is concluded to be a novel ECE inhibitor with distinct in vivo activity. Since AM-A and -B were ineffective in mitigating ET-1-induced responses (sudden death and hemoconcentration) in vivo, alleviation of bET-1-induced responses by these chelators was confirmed to be 
due to inhibition against ECE. These compounds can be utilized as pharmacological and enzymological tools to investigate the role of ECE and ECE itself.

\section{REFERENCES}

1 Yanagisawa, M., Kurihara, H., Kimura, S., Tomobe, Y., Kobayashi, Y., Mitsui, Y., Yazaki, Y., Goto, K. and Masaki, T.: A novel potent vasoconstrictor peptide produced by vascular endothelial cells. Nature 332, 411-415 (1988)

2 Ohnaka, K., Takayanagi, R., Yamauchi, T., Okazaki, H., Ohashi, M., Umeda, F. and Nawata, H.: Identification and characterization of endothelin converting activity in cultured bovine endothelial cells. Biochem. Biophys. Res. Commun. 168, 1128- 1136 (1990)

3 Warner, T.D., Mitchell, J.A., D'orleans-Luste, P., Ishii, K., Forstermann, U. and Murad, F.: Characterization of endothelin-converting enzyme from endothelial cells and rat brain: detection of the formation of biologically active endothelin-1 by rapid bioassay. Mol. Pharmacol. 41, $399-403$ (1992)

4 Matsumura, Y., Ikegawa, R., Tsukahara, Y., Takaoka, M. and Morimoto, S.: Conversion of big endothelin-1 to endothelin-1 by two types of metalloproteinases of cultured porcine vascular smooth muscle cells. Biochem. Biophys. Res. Commun. 178, $899-905$ (1991)

5 Matsuura, A., Okumura, H., Ashizawa, N. and Kobayashi, F.: Big endothelin-1-induced sudden death is inhibited by phosphoramidon in mice. Life Sci. 50, $1631-1638$ (1992)

6 Matsumura, Y., Hisaki, K., Takaoka, M. and Morimoto, S.: Phosphoramidon, a metalloproteinase inhibitor, suppresses the hypertensive effect of big endothelin-1. Eur. J. Pharmacol. 185, $103-106$ (1990)

7 McMahon, E.G., Palomo, M.A., Moore, W.M., McDonald, J.F. and Stern, M.K.: Phosphoramidon blocks the pressor activity of porcine big endothelin-1-(1-39) in vivo and conversion of big endothelin-1-(1-39) to endothelin-1-(1-21) in vitro. Proc. Natl. Acad. Sci. U.S.A. 88, 703-707 (1991)

8 Okumura, H., Ashizawa, N., Matsuura, A. and Kobayashi, F.:
Comparison of hemoconcentration induced by endothelin-1 and big endothelin-1 in mice. Japan. J. Pharmacol. 61, Supp. I, 232P (1993)

9 Lehoux, S., Plante, G.E., Sirois, M.G., Sirois, P. and D'orleans-Juste, P.: Phosphoramidon blocks big-endothelin-1 but not endothelin-1 enhancement of vascular permeability in the rat. Br. J. Pharmacol. 107, 996-1000 (1992)

10 Okada, K., Miyasaki, Y., Takada, J., Matsuyama, K., Yamaki, T. and Yano, M.: Conversion of big-endothelin-1 by membrane-bound metalloendopeptidase in cultured bovine endothelial cells. Biochem. Biophys. Res. Commun. 171, $1192-1198$ (1990)

11 Matsumura, Y., Ikegawa, R., Tsukahara, Y., Takaoka, M. and Morimoto, S.: Conversion of big endothelin-1 to endothelin-1 by two types of metalloproteinases derived from porcine aortic endothelial cells. FEBS Lett. 272, 166-170 (1990)

12 Yano, M., Okada, K., Takada, J., Hioki, Y., Matsuyama, K., Fukuroda, T., Noguchi, K., Nishikibe, M. and Ikemoto, F.: Endothelin-converting enzyme and its in vitro and in vivo inhibition. J. Cardiovasc. Pharmacol. 17, Supp. 7, S26-S28 (1991)

13 Haenni, A.L., Robert, M., Vetter, W., Roux, L., Barbier, M. and Lederer, E.: Structure chimique des aspergillomarasmine $A$ et B. Helv. Chim. Acta 48, 729-750 (1965) (in French)

14 Barbier, M.: Marasmin-Fe $\mathrm{e}^{3-}$ chelates catalyzed photooxidations in plant leaves as a mechanism for their biological activity through bio-Fenton reactions. Photobiochem. Photobiophys. 7, 53-57 (1984)

15 Mikami, Y. and Suzuki, T.: Novel microbial inhibitors of angiotensin-converting enzyme, aspergillomarasmines $\mathrm{A}$ and $\mathrm{B}$. Agric. Biol. Chem. 47, 2693-2695 (1983)

16 Bush, K.: Evaluation of enzyme inhibition data in screening for new drugs. Drugs Exp. Clin. Res. XII, 565-576 (1986)

17 Fukuda, Y., Hirata, Y., Yoshimi, H., Kojima, T., Kobayashi, Y., Yanagisawa, M, and Masaki, T.: Endothelin is a potent secretagogue for atrial natriuretic peptide in cultured rat atrial myocytes. Biochem. Biophys. Res. Commun. 155, 167-172 (1988) 